\title{
DISCUSSION PAPER:
}

Reengineering Destination Marketing Organisations The Case of Switzerland

\author{
Prof. Dr. Thomas Bieger \\ 33RD TRC-MEETING BRIJUNI (CROATIA) \\ 15TH-18TH MAY 1998
}

\section{CONTENTS}

1. New Structures for alpine tourism

1.1. The challenge of globalisation

1.2. Destinations as strategic business units in tourism

1.3. A concept for new structures in alpine tourism marketing based on destinations

2. Change in Switzerlands tourism structures - first experiences

2.1. Analytical framework

2.2. Survey of practical experiences

3. Conclusions

3.1. Role of the different agents

3.2. Change strategy

3.3. Outlook: from a institutional to a product based perspective 


\begin{abstract}
Like most traditional forms of tourism also alpine tourism has lost its strategic success positions due to the ongoing globalisation of the tourism sector. The traditional structures in tourism marketing - based on political and institutional boundaries - have to make place to a more market oriented structure. The association of swiss tourism managers decided to follow a destination management approach that will lead to corresponding tourism structures. A proposition for such structeres has been presented last year.

So far, a large number of regional and local tourism organizations have undertaken reengineering projects to put the new structures into work. A short overview over different experiences of the last year leads to different conclusions. For example:

- which are the most successful and powerful driving forces in the change process,

- what are the major topics for the reengineering projects.

This paper presents the destination structure concept and tries to provide arguments for it (based on a presentation for the annual meeting of EUTO). In the second part a synoptic overview of different ongoing reform projects is given based on an analytical framework (extracted our institutional experiences from consulting work or as head of a subcommittee of the Swiss association of tourist managers). A third part consists of conclusions.
\end{abstract}




\section{NEW STRUCTURES FOR ALPINE TOURISM}

\subsection{The Challenge of Globalisation}

Since the early 1990s the traditional tourism centres, especially in Europe, have experienced a dramatic change in tourism demand (Weiermair, 1996; De Keyser/Nanhove, 1997). Cheap airline transport, new information technologies such as the internet and global distribution systems, as well as travel experienced customers, have led to a fast globalization in tourism demand. Tourists satisfy their travel needs in destinations all over the world, depending on the specific travel motivation. Therefore, customer loyalty is decreasing. While global tourist demand is increasing by six and more percent annually, demand in Switzerland is decreasing by annual rates of 3 to $4 \%$ (Figure 1).

\section{Figure 1: Development of worldwide arrivals in comparison with Switzerland}

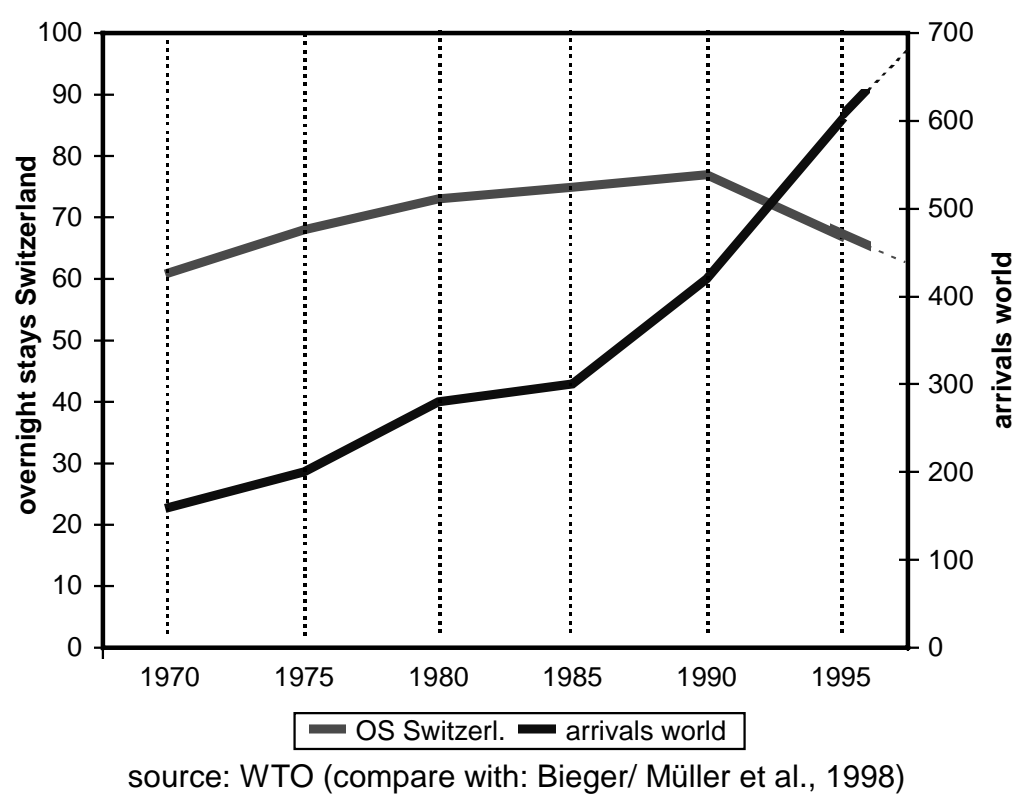

Obviously traditional strategic success positions are devaluated. This first part tries to outline why the strategic success positions of traditional tourism centres are not important anymore, what the new trends in tourism demand are and what challenges the tourism organizations in charge of cooperative marketing are facing.

\subsubsection{Loss of traditional strategic success positions in alpine tourism}

For decades the traditional European tourism countries could rely on the following factors:

1. demand

- demand for simple products such as single purpose vacations (hiking holidays, ski holidays)

- inexperienced customers who were afraid of foreign destinations and high transport costs

2. factors

- cheap, skilled labour, cheap capital and untouched nature 


\section{3. industry network}

- inspiring cluster of sports equipment producers, transport system producers, innovative hotellerie, sportscentres with good infrastructure, etc.

\section{4. management capacity/strategy}

- stakeholder orientated management which took care of the problems and fears of the destination's citizens

Under these market conditions, strategic success positions such as

- close distance to densely populated areas in Central Europe,

- small and medium sized enterprises with close contact to their loyal customers,

- decentralized production structures with a large number of independently operating companies specialized in single functions,

- production processes relying on human work and expensive infrastructure,

- management with highly developed political skills able to legitimate nearly uncontrollable funds

led to an economic success.

Figure 2: Traditional success factors for alpine destionations

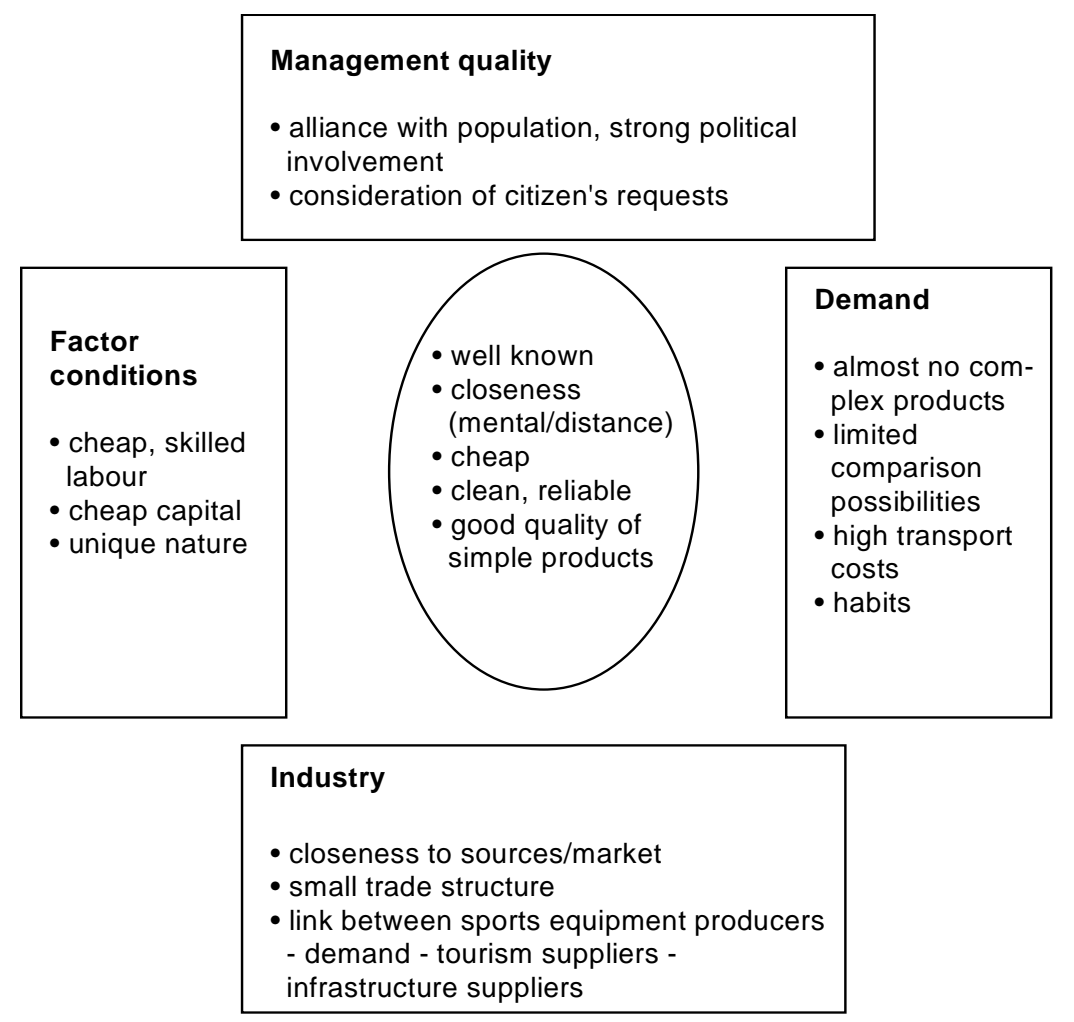

source: Bieger (1998.1), p. 7.

Now the growth rules of the market have changed:

\section{1. demand}

Customers ask for integrated service chains able to fulfill problem solving functions or to offer new forms of holiday experiences. Most customers are experienced travellers able to compare prices and quality. New destinations come into the market, part of them profiting from huge state subsidies, enabling them to earn foreign exchange. These new destinations can easily be reached by cheap air transport. 


\section{2. production factors}

Wages have risen in European tourism areas because of the industrialization and the wage shifts stemming from other service industries such as banking. Capital costs are high, which can be put down to overinvestments made in times of low interest rates. The tourism industry isn't seen as a low risk industry anymore and therefore the interest rates are rising.

\section{3. industrial networks}

Small and medium sized enterprises are still dominating the industry. But many of the sports equipment companies have disappeared in a concentration process. Hence the possibilities for product innovations have diminished. The snowboard for instance hasn't started its success story in the European Alps.

\section{4. management capacity/strategy}

A strong, politically orientated management is still following strategies concentrating on preservation and regulation.

\section{Figure 3: Service chain of an alpine destination}

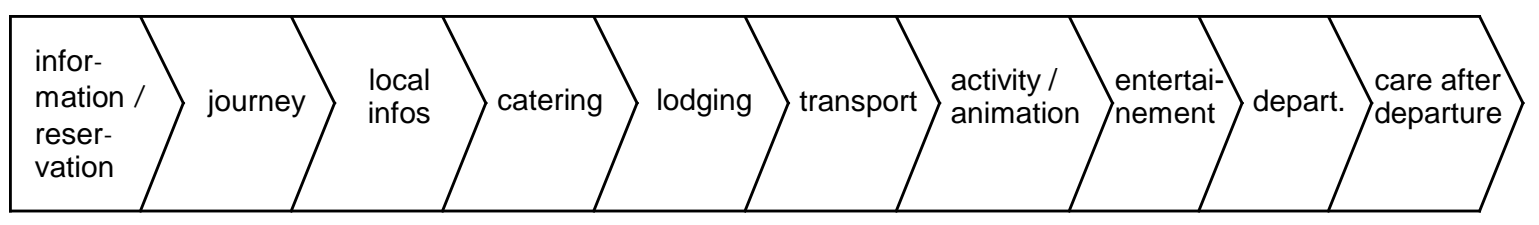

source: Bieger/ Müller et al., 1998 p. 27.

\subsubsection{Trends in tourism demand}

As mentioned above, modern tourists have become critical regarding prices and quality. Moreover, high income market segments are critical about time efficiency. For guests belonging to this segment experiences per minute have to be maximized. These tourists are swamped with information about new destinations. Hence they rely on the information of relatives and friends or stick to strong brands. They ask for experiences and authenticity as a contrast to the ever growing routine duties of a more and more artificial world. It doesn't mean that they like to have the original. What does it matter if it's real or not? If it's real enough for the customer, he will buy it (Poon, 1993).

Therefore tourism products must meet the following demands:

- based on integrated service chains, which allow the highest possible convenience for the customer (Bieger/ Müller et al.1998)

- promoted as strong brands (Bieger 1992 and 1997)

- distributed by a fast just in time system which enables the customer to make reservations everywhere, anytime and with immediate response (Bieger/ Müller et al., 1998)

- consisting of integrated service products allowing the customer to choose from a multi-optional offer (Poon, 1993). 


\subsubsection{New challenges for destination tourism organizations}

Tourism organizations have to fulfill promotional and organizational functions to assure the competitiveness of their destinations, areas or countries. Following the new logic of the market they therefore have to:

1. make sure that bookable products with a good price/value ratio are offered by cooperations of different partners along the whole service chain.

2. follow a brand policy that leads to a better market transparency and customer orientation.

3. operate a reservation system which is able to serve as many point of sales as possible.

4. assure a certain range of activities by cooperating with suppliers and other destinations. In a certain sense tourism organizations have to play a key role in motivating cooperations between different partners in tourism. Horizontal cooperations to ensure economies of scale, vertical cooperations to ensure economies of scope (Keller/Koch, 1995).

Figure 4 shows the driving forces for cooperations at destination level and the need for bigger business units.

Figure 4: Driving forces for cooperations in tourism

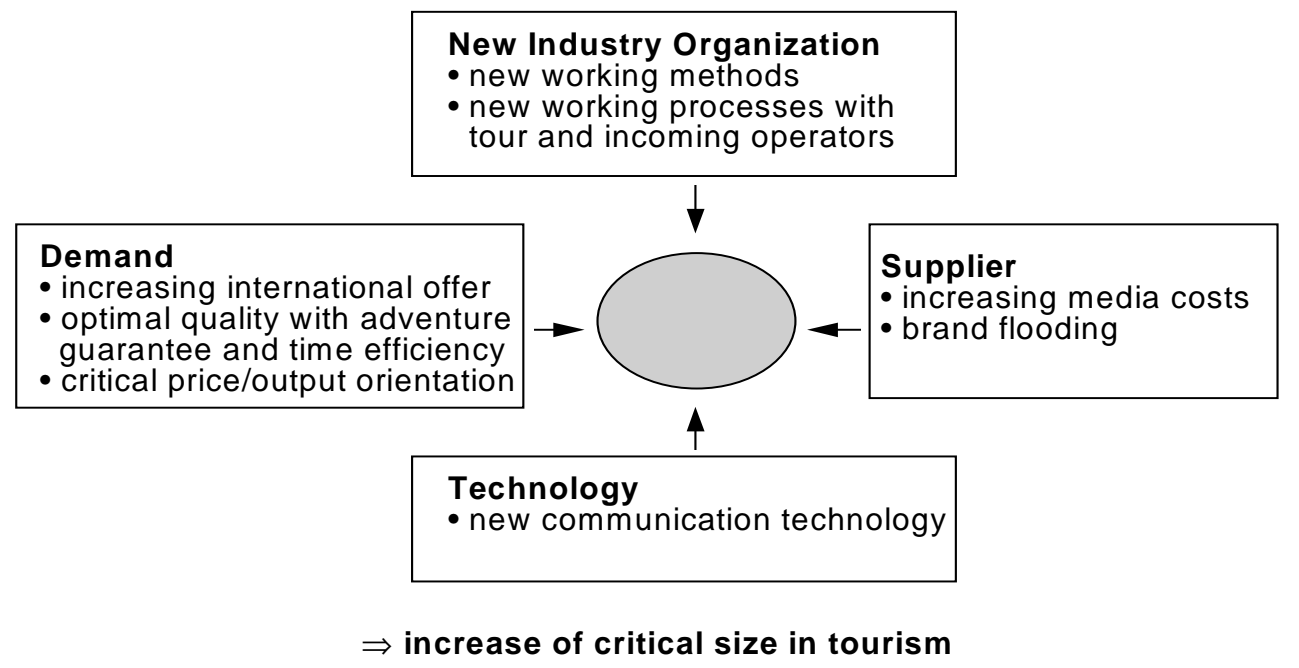

\subsection{Destinations as strategic business units in tourism}

Especially in traditional tourism countries where the industry consists of a large number of independently operating small and medium sized enterprises, the question of the critical size of a unit managed and co-ordinated by a tourism organization arises. In the following sections I would like to outline briefly the traditional structure of tourism organizations in Switzerland, which are quite similar to the structures in Germany or Austria. As a new concept for tourism organizations structures, the destination concept will be shown and the functions of a tourism organization at destination level will be depictet.

\subsubsection{Inefficiencies of the old tourism structure}

The current structure of tourism organizations in Switzerland is a hierarchic one. There are tourist organizations at a local, regional, state (Cantons) and national level. Together 
with the individual enterprises they all do their own marketing. So hundreds of different brands are promoted in Swiss tourism.

Every level does some coordination work. If for example the Swiss national tourist office were to start a campaign with specific products it would take weeks to get the offers of the different enterprises and hotels, because state, regional and local level organizations have to communicate together. In a market with time based competition, speed-management is a key factor.

At every level political work is done. Only at national level the tasks are devided between the Swiss national tourist office (responsible for the marketing) and the Swiss tourism association (responsible for the political lobbying). At state, regional and local level, marketing and lobbying is performed by the same organization, by the same people. Therefore many conflicts concerning goals arise. Because all these tourist organizations have a political function, they have to be neutral in their work with the private enterprises most of which are members of these organizations. Therefore they are not able to guarantee quality control, to secure hard selling or to ask good prices from the hotels and other partners.

All these tourism organizations work for areas within political borders. On the other hand, in most cases, the area that the tourist regards as a product and in which he consumes his services during his stay, is independent of political borders. Therefore an efficient coordination of the tourist product can't be guaranteed by these political organizations.

The main disadvantages of the traditional structure can be summarized as following:

- unfocused, dispersed marketing efforts mostly below any critical size

- unable to perform hard selling and quality control

- conflicts of goals between political targets and marketing necessities

- insufficient product coordination

\subsubsection{Destinations, products and strategic business units in tourism}

The destination concept focus on customers and producers. Destinations can be defined as areas which consist of all services and offers a tourist consumes during his/her stay (Bieger, 1992 or WTO, 1993). A destination can therefore be seen as the tourist product that in certain markets competes with other products. These products are always relevant for certain market segments. Hence destinations must be defined according to market segments. In most cases a destination has to be the bigger the farer away a tourist is. For a Japanese tourist coming to Europe for example five or six European countries are the destination. On the other side, for a German tourist coming to ski holidays to the Swiss Alps one village may be the destination. Therefore tourism organizations have to be defined to markets.

Because the markets linked to the products are quite stable, destinations may be seen as strategic business units from the management point of view (Müller, 1995 or Bieger, 1997).

The destination concept leads to a new paradigm in tourism organizations because it is:

- customer focused

- process oriented

The focus is not on industries and enterprises anymore, but on service chains. A $90^{\circ}$ shift of the management perspective, i.e. from a functional to a process view, is necessary. 


\section{Figure 5: Reengineering in tourism}

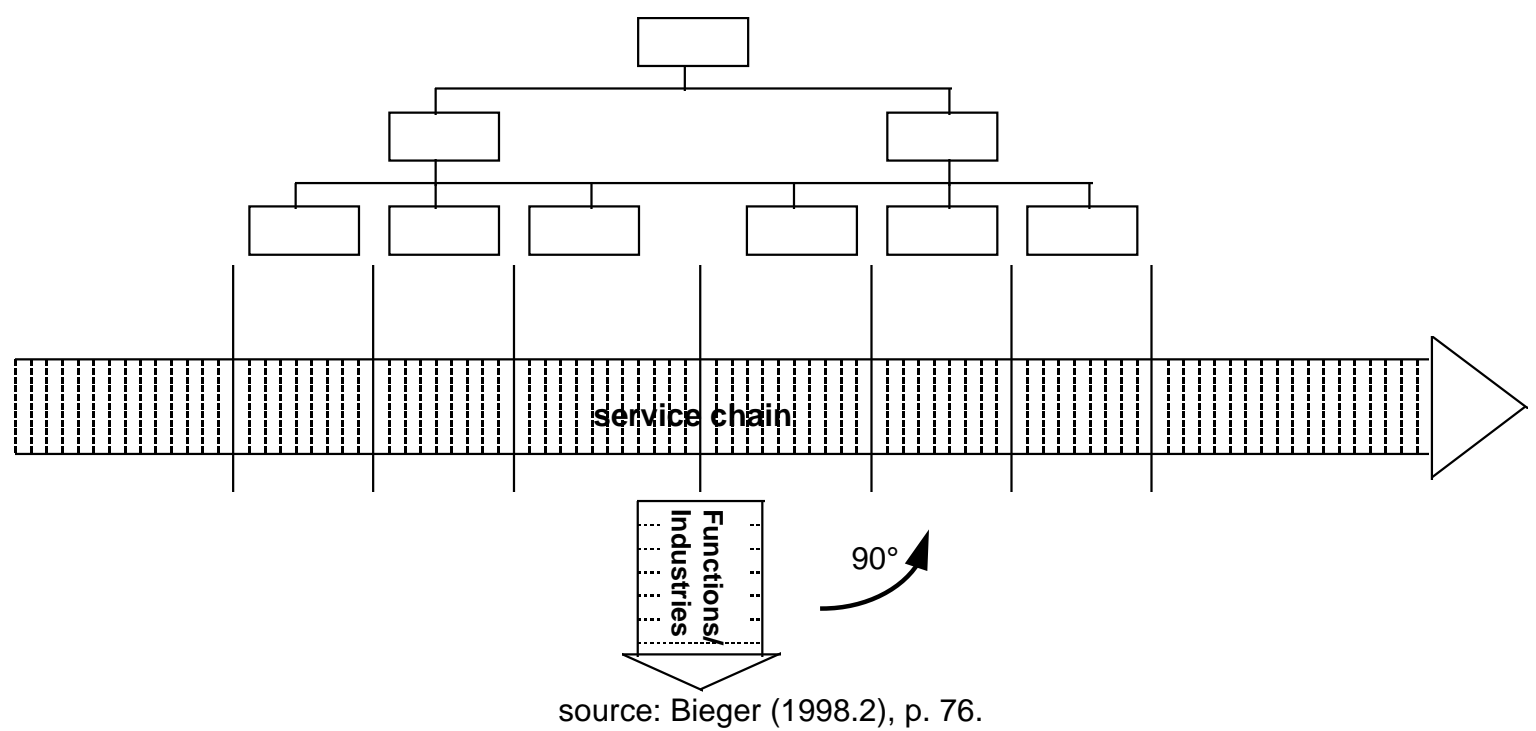

Because in most tourist areas one form of tourism is dominating, it is most reasonable to define a destination out of this segment. For example in a Swiss mountain village, the most important form of tourism and the one that offers the largest income is the winter sports business. Therefore the destination has to consist of all the services and prestations consumed by a winter holiday guest. These destinations have to be managed as strategic business units by destination management companies or in our terminology by tourism organizations at destination level. This destination management companies must comply with the requirements of section 1.1.3. Certain demands concerning financial resources, professionalism and opportunities have to be met to form a brand.

\subsection{A concept for new structures in alpine tourism marketing based on destinations}

\subsubsection{Basics}

An expert group has worked out the conditions for effective destinations and a new tourism organization structure, based on the destination concept. The main criteria for a destination are shown in figure 6.

\section{Figure 6: Criteria for a destination}

- Independence from political limits and primary concentration on a destination. (Area from the guest's perception. Example: region or city).

- Within a destination the offer for the guest includes all the necessary facilities such as entertainement, lodging, transportation, etc.

- The destination has at least one independent brand and qualified personnel. Depending on the range of the brand the necessary available funds are shown in figure 7.

- Obligation to offer starting points for the creation of new brands (supraregional known sights, special farming products, etc.).

- It is necessary to build up reservation facilities/ points of sale, which create and commercialize new offers or provide the facilities to distribute within such channels with the help of modern media.

source: Bieger/ Müller et al., 1998, , p. 24. 
The range of marketing activities depends on the available marketing budget respectively the number of overnight stays (as a proxy for the income generated in tourism).

Figure 7: Range of marketing activities of tourism organizations

\begin{tabular}{|l|l|l|l|}
\hline Category & Range & Funds & $\begin{array}{l}\text { Overnight stays (OS) } \\
\text { (resp. equivalent value } \\
\text { added by other forms of } \\
\text { tourism such as day- } \\
\text { tourism) }\end{array}$ \\
\hline National players & $\begin{array}{l}\text { Switzerland, resp. selected } \\
\text { segments in Switzerland }\end{array}$ & $\begin{array}{l}\text { mutual marketing funds, at } \\
\text { least Sfr. 500'000, total } \\
\text { budget Sfr. 1'000'000 }\end{array}$ & 300 '000 OS \\
\hline International players & $\begin{array}{l}\text { Switzerland and selected } \\
\text { close foreign markets }\end{array}$ & $\begin{array}{l}\text { mutual marketing funds, at } \\
\text { least Sfr. 1'000'000, total } \\
\text { budget Sfr. 2'000'000 }\end{array}$ & 600 '000 OS \\
\hline Global players & $\begin{array}{l}\text { Specific markets in other } \\
\text { continents }\end{array}$ & $\begin{array}{l}\text { mutual marketing funds, at } \\
\text { least Sfr. 2'000'000, total } \\
\text { budget Sfr. 4'000'000 }\end{array}$ & 1 Mio. OS \\
\hline
\end{tabular}

source: Bieger/ Müller et al., 1998, p. 25.

\subsubsection{Functions of a tourism organization at destination level}

As destinations are strategic business units, they have to be managed with competitive strategies. Considering the requirements mentioned in section 1.1.3. as well as the general functions of a tourism organization (marketing, offer coordination, political lobbying and planning (Bieger 1997 or Heath/Wall, 1992)), the following tasks are to be met by destination management companies (figure 8).

\section{Figure 8: Functions of destination management companies}

\section{TASKS WITHIN A DESTINATION}

The destination, respectively the newly defined SBUs must meet the following requirements:

\section{Planning}

- Working out a development model

- Developing a destination strategy (competitive and corporate strategy)

\section{Product development}

- Operating a central information office (data base) and an information desk

- Creating marketable products

- Guaranteeing guest care and animation

- Operating a quality development and securitization system with the help of service chains

- Guaranteeing management and front personnel training

- Guaranteeing a complaint office

- Organization of (big) events 


\section{Marketing}

- Developing a marketing strategy

- Guaranteeing market research respectively analysis of opinion polls concerning the destination

- Guaranteeing a brand management (positioning, maintenance, cooperation strategies) depending on the range of the brand/ market

- Guaranteeing the image marketing, promotion and public relations

- Defining a price strategy for products in the destination's distribution system

- Active selling and operation of a central reservation office/ incoming function with guaratee of a distribution system and creation of marketable products

4. Pool

- Information of industry and population

- Promoting the tourism awareness

- Political pools for special projects - but no political work for general conditions

source: Bieger/ Müller et al., 1998, p. 32f.

Currently, there are only a few local tourism organizations meeting the requirements mentioned in section 1.2.2., able to provide the functions highlighted in section 2.3. In most cases, tourism organizations at local level have to be merged to become a bigger and more effective unit. In the following sections, the structure of a destination management company and the necessary transforming strategies for local tourism organizations will be outlined. Because this transformation requires a dramatic change management resistance to change is discussed considering the role of the different partners.

\subsubsection{Structure of a destination management company}

A destination management company must be efficiently funded and provided with operational freedom to do a professional job. The type of cooperation structure (association, joint stock company, etc.) is a matter of secondary importance. The operational freedom for the management and the professionalism of the board members is of primary concern. In case of most of them being politicians, it is be very unlikely that market focused competitive strategies will be followed.

Within the destination management company, product managers have to be put in charge of the different market segments. They are responsible not only for the product creation and distribution but for the the corresponding coordination, too.

Figure 9 shows a possible organization structure of a destination management company based on a matrix structure. 


\section{Figure 9: Destination management company}

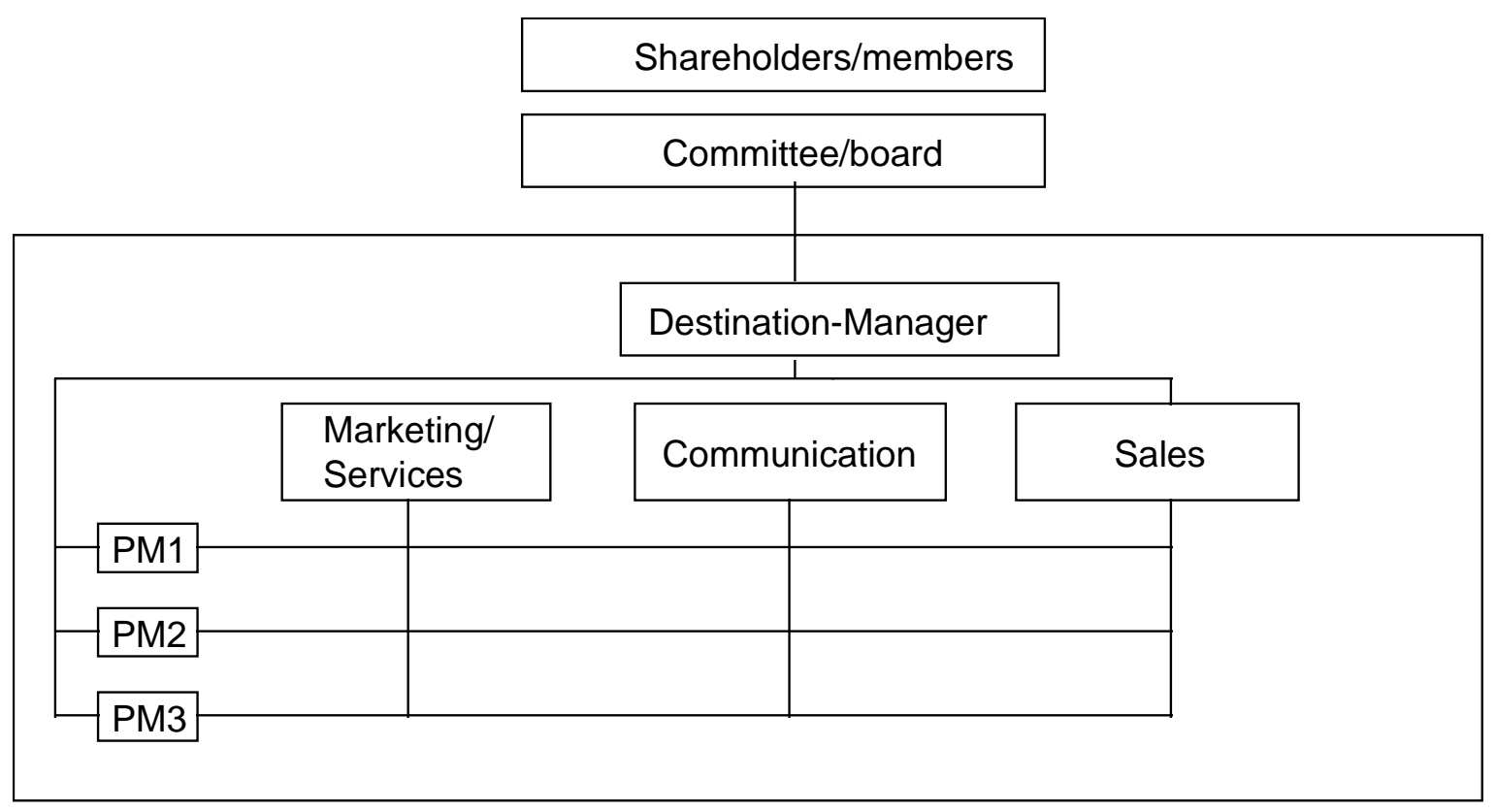

In these destination management companies, new professions emerge. Instead of tourism organization managers, product and destination managers will be needed.

The destinations are directly linked with the market either by their own marketing activities or by global distribution systems. Therefore the regional and state tourism organizations are no longer responsible for any marketing or product coordination functions. Nevertheless, they have to keep on lobbying at state level in order to coordinate regional planning. Because economies of scale arise in certain marketing functions it seems reasonable to put these regional and state tourism organizations in charge of specific marketing service functions such as marketing information or media contracting.

Figure 10: The new responsibilities in Swiss tourism

\begin{tabular}{|c|c|c|c|c|c|}
\hline & TO local & destination & TO regional & ST & STV \\
\hline Planning & $\begin{array}{c}\text { model } \\
0 \\
\end{array}$ & $\begin{array}{c}\text { model } \\
\text { and } \\
\text { strategy }\end{array}$ & $\begin{array}{c}\text { model } \\
\mathrm{O}\end{array}$ & strategy & $\begin{array}{c}\text { support } \\
\text { model } \\
0 \\
\end{array}$ \\
\hline $\begin{array}{c}\text { Offer } \\
\text { creation }\end{array}$ & information & $\begin{array}{c}\text { product } \\
\text { development, } \\
\text { quality systems, } \\
\text { etc. } \\
\bullet\end{array}$ & $\begin{array}{l}\text { regional coor- } \\
\text { dination } \\
\text { relevant to } \\
\text { market } \\
0\end{array}$ & $\begin{array}{c}\text { national coor- } \\
\text { dination } \\
0\end{array}$ & consulting \\
\hline Marketing & --- & $\bullet$ & $\begin{array}{l}\text { service } \\
\text { center }\end{array}$ & $\bullet$ & $\begin{array}{c}\text { consulting } \\
---\end{array}$ \\
\hline Pool & $\bullet$ & $X$ & $\begin{array}{c}\text { evtl. } \\
0\end{array}$ & $X$ & $\bullet$ \\
\hline Fund rising & $X$ & $X$ & $X$ & $X$ & $\bullet$ \\
\hline
\end{tabular}

\footnotetext{
$X \quad$ project specific

- very important

of small importance

--- of no importance

source: Bieger/ Müller et al., 1998, p. 38.
} 
The destination management companies must be financed appropriately to their task and function. Because all their prestations have the character of a public good, private financing is impossible (Boehan/Mak, 1996 or Mühlenkamp, 1997).

Specific taxes have to be introduced. The expert group suggests a business tax from all benefitting companies within the destination in order to finance tourism marketing, a tourism tax from the guest to finance the public prestations and the product coordination and public subsidies to finance the destination planning as a part of the regional planning process.

\section{CHANGE IN SWITZERLAND TOURISM STRUCTURE - FIRST EXPERIENCES}

\subsection{Analytical Framework}

During the past year, several regional and local tourism organisations have untertaken reform projects. It seems impossible to give a complete overview over all projects. $\mathrm{Ne}-$ vertheless we try to mention the most important projects on regional level and the most recent on a local level in Eastern Switzerland. It would take to much time to characterize each project in detail. Therefore we try to give a synoptical overview based on general adoptable criterias that cover general direction and the character of the change process.

\subsubsection{Direction of Change}

The direction of change can be characterized by the starting point (factors enforcing a reform) and the target point (general goal or strategy of the reform). Based on the general conditions and lines of the new destination structures presented in chapter one, the following specifics can be identified:

\section{starting point}

- lack of finance (diminishing budgets for marketing acivities or even danger of illiquidity because administrative costs exceed revenues)

- strategic development goals of the tourism organization or its manager (the organization or its management realize the necessity to adopt to new business logics to prevent legitimacy problems later on and to secure a strategic development of the organisation and its managers)

- political pressure (politicians and bureaucrats under intensified budget rigidity ask for a better effectiveness and effeciency of publically funded tourism organizations)

- pressure from members, especially tourism companies (tourism companies and its managers realize the necessity of a efficient and effective coorporative marketing)

\section{target point}

- redefinition of the tasks (aimimg at tasks according to the organizations core competencies in line with the destination concept accorting to chapter 1.3.)

- enlargement of the area served (strong tourism organisations try to get in charge of the tourism marketing of surrounding areas to get more funds and to reach a critical size)

- merger with other tourism organisations (some tourism organisations try to reach a critical size and to cover the whole area that forms a destination in the eyes for a customer through a merger with a neighbouring organisation)

- founding of a new organization (to cover the whole area that forms a destination in the eyes of a customer) 


\subsubsection{Character of the change process}

Management theory suggest several methods for the management of strategic change. These theories can be characterized by two extreme concepts (s. Thom, 1997), the business reengineering approach (Hammer/Champy, 1993) and the organizational development approach (Thom, 1992).

Business reengineering deals with the idea of thinking the business over with the goal of a quick success. Oftenly, the starting point is a position, reduced to the question: „How would we do it now, if we could restart again?" Then, changes are carried through within a short time by a small group, almost like a surprise attack. Organizational development consists of an evolutive character. It assumes that the system can't change itself before the attitude, values and behaviour of the members of a sozio-technical system have been changed. (Thom, 1997, p. 205.) Condition for that is, of course, the image of mankind, assuming an individual beeing capable of development, educable and responsible allembracing thinking. Organizational development has different phases: Starting-point is the common knowledge of an inperfect persence, followed by the shared definition and enforcement of an new situation (unfreeze $\Rightarrow$ change $\Rightarrow$ freeze).

According to Thorm (Thom, 1997, p. 210.), there are different strengthes, depending on their approach:

\section{Business Reengineering}

- possibilities of new beginnings

- opportunity to improve efficiency drastically

- quickness of change

- conceptional homogenity of the changing measures (general process-perspective)

- significant competence enlargement for „process specialists“

\section{Organizational development}

- social agreeableness on account of natural change

- consideration of the development-possibility of the system-members

- support of self-management respectively self-organisation

- long-term point of view

- avoidance / reduction of changing-opposition

For destinations, there are circumstances additianally complicating the management of strategic change.

Main points for the enterprises are:

- meeting with the employes' fear. That fear, consists of dealing with possibly giving up a known situation in favour of a unknown or, concerning qualification / standard demands, loss of power and existing positions.

- dealing with the positions of interests of different departments, which have to give up ressources or gain new ones during restructuring.

Strategic chance in tourism is not only a question of changing processes organization structures and employees. It's rather a chance involving the culture and identity of locals as base of political power. It affects therefore questions of legitimation (s. Bieger 1997 and Bieger/Beritelli 1996.)

From the point of view of the destinations, one has to consider

- the identity of the population, often not directly related to the tourism

- the covering of the political distribution of power and interests 
- the fact that there is no central leadership

- for essential decisions (for example future subsidy of the tourism-organisation, spaceeffective decisions) affected people only take part in a small way. This circumstance calls for special information and communication needs.

The change management mainly deals with the cosequences as shown in figure 11.

\section{Figure 11: Consequences for the change management and suitability of the methods}

\begin{tabular}{|lll|}
\hline $\begin{array}{l}\text { guaranteeing the identity of } \\
\text { the inhabitants }\end{array}$ & $\Rightarrow$ & professional definition of a service-culture \\
\hline $\begin{array}{l}\text { guaranteeing political sup- } \\
\text { port }\end{array}$ & $\Rightarrow$ & changing of values within an OE-disposition \\
\hline $\begin{array}{l}\text { guaranteeing a common } \\
\text { sense, aimed on overall } \\
\text { interests }\end{array}$ & $\Rightarrow$ & powerful leader \\
\hline $\begin{array}{l}\text { Limitations / Restrictions: } \\
\text { - no clear leadership } \\
\text { - many only partial affected people are involved (politically and socially) }\end{array}$ & & business-competent and powerfull steering- \\
\hline
\end{tabular}

The experiences of management show that the way of prcedure has to be consistent. In this way all stages between business reengineering and organisational development are possible. Extreme positions, as shown in figure 12, would not be successful. Involving the affected people without working on their thinking but only follow up a technocratical process solution, would not be possible. Changing the thinking of all affected persons without their partizipation wouldn't be possible either.

Figure 12: Approaches change management

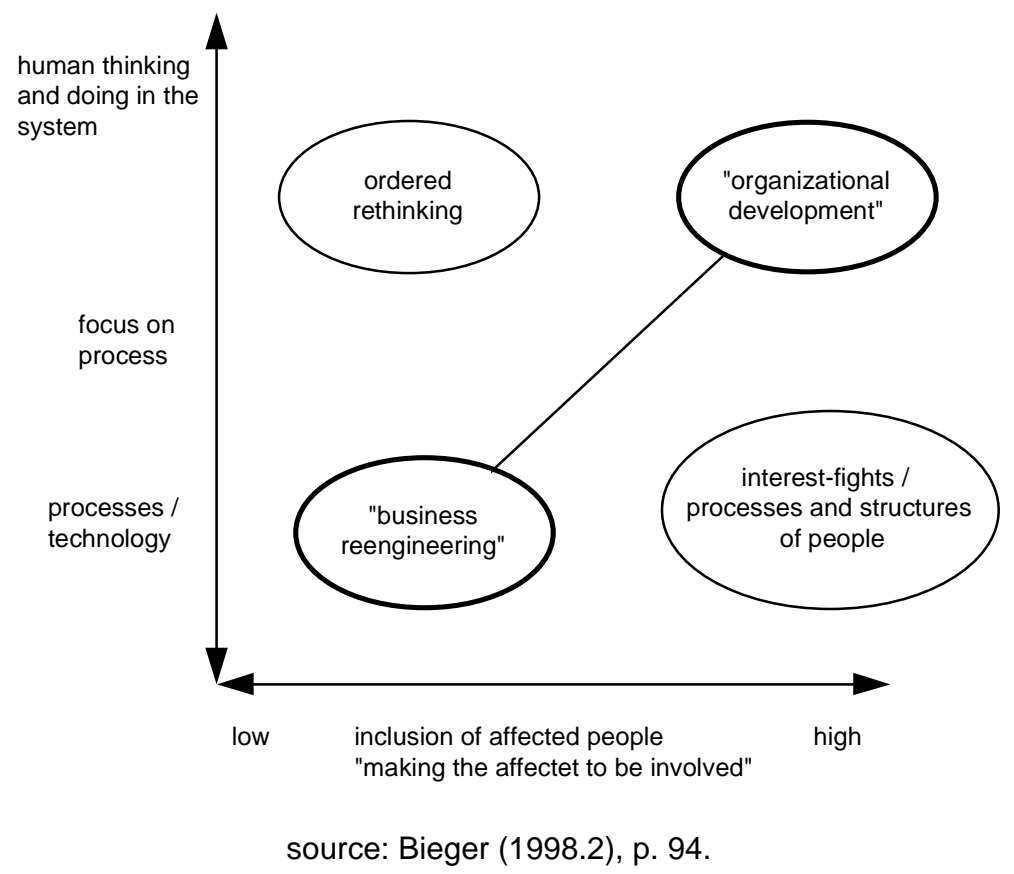

It therefore should be possible to characterize a change process by using the following criterias: 
- Driving forces of the change (because of the necessity for legitimacy and the lack of direct lines of command there is a gereral accepted powerful change leader/change agent needed)

- Degree of public involvement (population and business sector)

- type of process (more evolutionary organizational development or a fast restructuring and reengineering)

- Support and management control (process owner/process manager)

\subsection{Survey of practical experiences}

Figure 13 and 14 show us a synoptical overview over recent projects of structural change in tourism marketing in Switzerland.

Figure 13: Touristic reform-projects in Switzerland (Part 1)

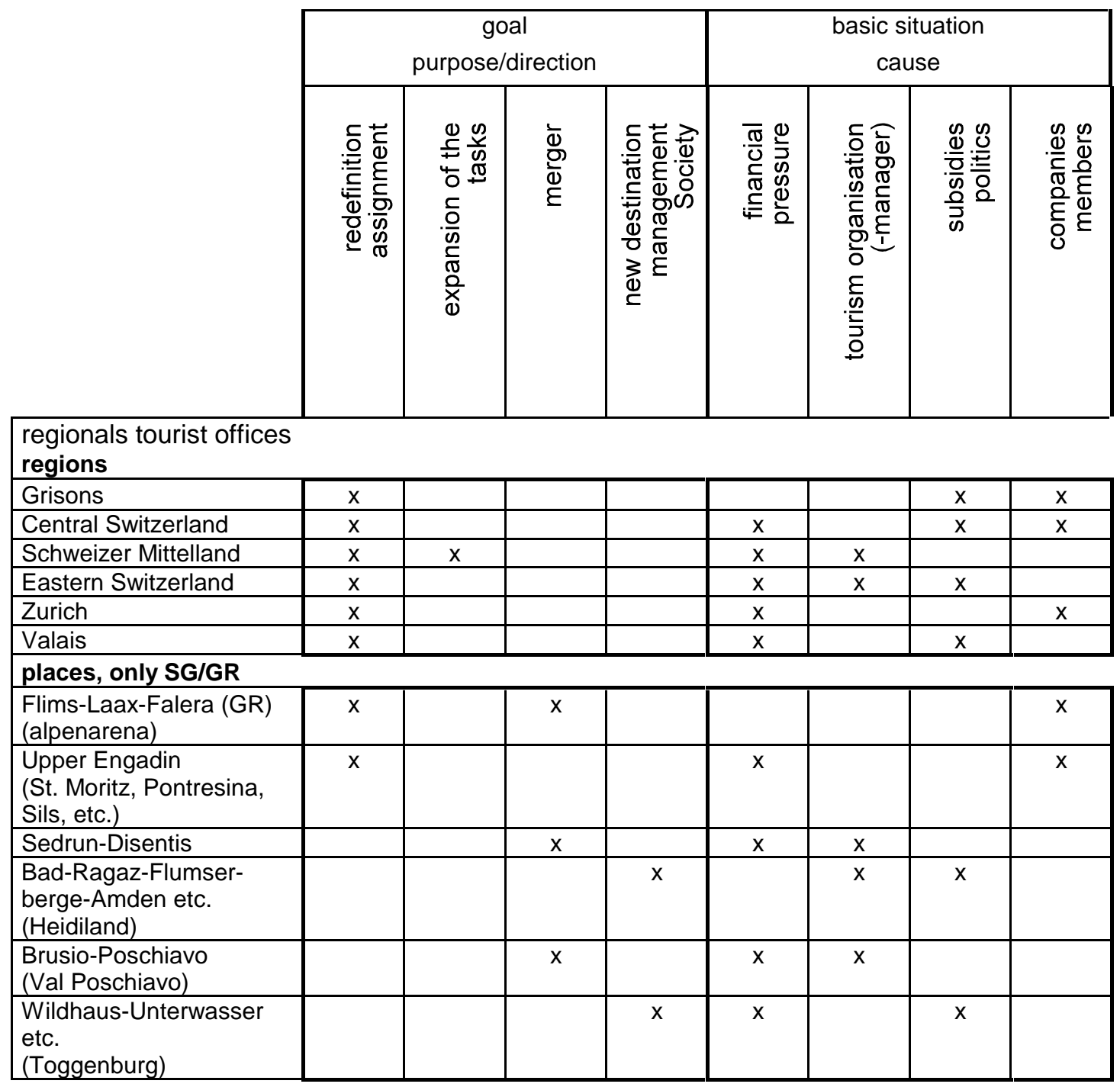


Figure 14: Touristic reform-projects in Switzerland (Part 2)

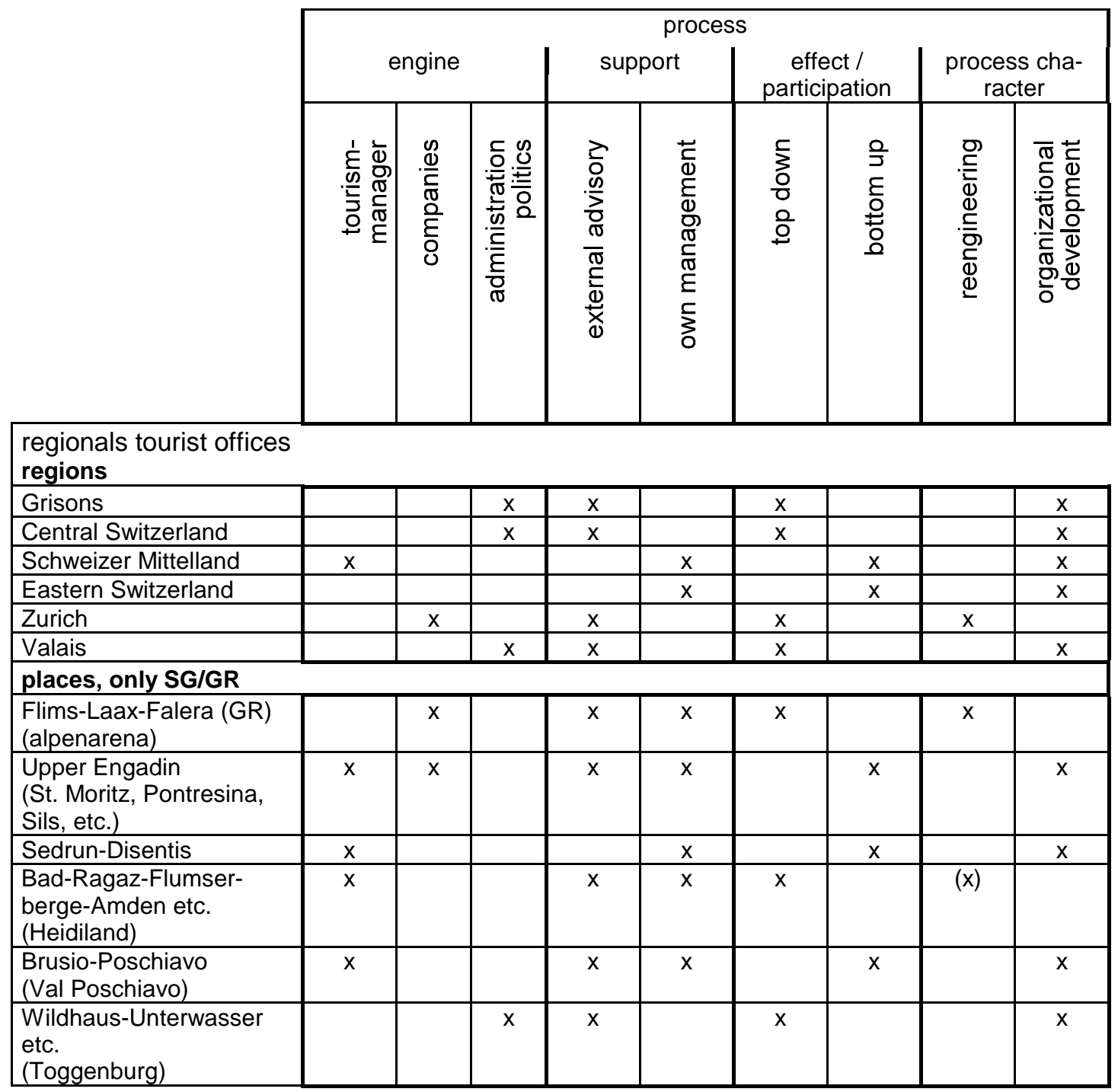

Concerning the redefinition of the tasks of the organizations, the following tendencies are prevailing:

\section{Figure 15: $\quad$ New definition of marketing assignments}

\begin{tabular}{|lll|}
\hline region region as servicecentre & $\begin{array}{l}\text { - redimensioning of image-advertising / renunciation of brand- } \\
\text { profiling } \\
\text { - renunciation of own marketing / pure marketing-service } \\
\text { functions }\end{array}$ \\
- comercializing of marketing / "selling“ of marketing platform \\
- extension of direct marketing / call centre \\
- taking over of the product-management-functions \\
- strengthening of the brand
\end{tabular}




\section{CONCLUSIONS}

From the presented cases different conclusions may be drawn. In general the directions of the reform projects are in line with the structural concept based on destinations. Still especially in areas of lesser touristic importance (and therefore a often neglectable economic importance of tourism) the projects in some cases are more political than market driven (for example in Aargau - Schweizer Mittelland). Politicians try to establish destination structures covering areas that can't be a destination for any tourism segment.

But the main problems seem to consist in the process itself especially if one considers the big number of tourism organizations realizing the necessity of change, but unable to even start a project.

\subsection{Role of the different agents}

On a regional level, most reform projects take advantage of the powerful driving forces stemming from a critical state government or bureacracy. The main reasons for this might be:

- the importance of the different states as sponsors of the regional tourism organizations

- the lack of an interested commercial sector (according to Olson's laws of collecitv logic (s. Olson 1965), a powerful interest group forms only, if there not to many members involved and therefore organizational and transactional costs are low. Typically, on regional level many companies in many destinations with different economic interests are involved).

On a local level, two major driving forces can be identified.

- First the tourism organizations and its managers themselves in an effort to guarantee the survival of their organizations and their jobs.

- Second the commercial sector, especially future oriented companies. The influence of these companies is the stronger the more they depend on the tourism cluster of the destination (which is especially true in the case of companies with tourists staying over night), the bigger they are and the smaller the number of equally big companies they have to coordinate with.

\section{Figure 16: Change catalyst}

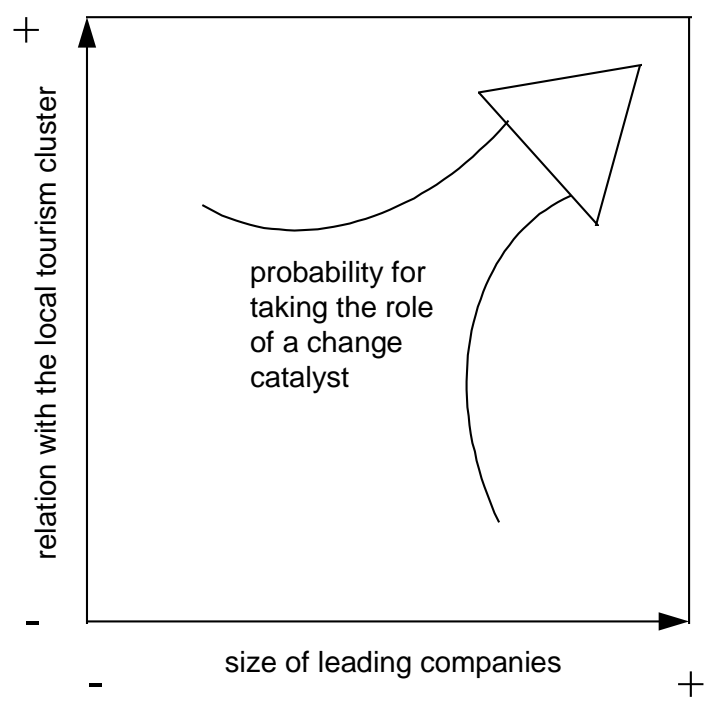


Depending on the level of the organization (state or regional) and the structure of the business sector there has to be found and committed a leader for the change.

\subsection{Change Strategy}

Top down reengineering processes seem to be successful in cases with generally accepted leaders. On the other hand, if there is no powerful and/or legitimated leader, a buttom up organzational strategy is necessary.

According to the change-strategy, different roles of the process owner can be identified. In the first case, a management or an outside consultant has to provice analytical work and develop concepts. The implementation is secured by the leader. In the second case, the change-owner likely has to be a outside consultant, who by his knowledge and his fame has the necessary legitimation. He therefore not only has to provide analytical work. He has an important role in implementation, too.

\subsection{Outlook: from an institutional to a product based perspecitve}

Reflecting the difficulties to make sure an efficient and successful change process on one hand and the still often wrong, not market oriented perspective of the direction of change on the other hand, we put to discussion the following theses:

1. There is a need for a cooperative fulfillment of basic functions in tourism that can be explained by the nature of the tourism product (intangibility etc.) and the structure of the tourism sector in traditional tourism areas (dominance of small and medium size enterprises). Such functions are mainly connected with information and therefore have to be financed by public funds because of thier public good character.

2. Marketing has to be focused on products. Therefore tourism organizations have only to be funded, if they are covering an area that in the eyes of potential customers forms a product.

3. There will be a broad field of new opportunities for marketing cooperations wiht product forms, for example along scenic routes or as homogenous cooperations consisting of members of the same branch in different areas. The state or local goverments have to decide, it there are receiving relevant external effects an if therefore a public legitimation of subsidies exist. 


\section{BIBLIOGRAPHY}

Bieger, Th./Beritelli P. (1996): Anpassung von Destinationsstrategien an die Globalisierung: Erfolgsfaktoren und Hemmnisse für den strategischen Wandel. In: AIEST (Hrsg.): Globalisierung und Tourismus, Publikation Nr. 38, St. Gallen.

Bieger, Th. (1997.1): Destinationsmanagement, 2. Aufl., München/Wien

Bieger, Th. (1997.2): Von der Gastfreundlichkeit zum professionellen Dienstleistungsprozess, in: die Unternehmung $3 / 97$

Bieger, Th. (1998.1): Einleitung: Reengineering der „Tourismus Schweiz AG“ Die Bedeutung neuer touristischer Strukturen für die zukünftige Wettbewerbsfähigkeit traditioneller touristischer Gebiete. In: Bieger, Th., Laesser, Ch. (Hrsg.): Neue Strukturen im Schweizer Tourismus - Der Weg der Schweiz. Zurich

Bieger, Th. (1998.2): Change Management in Destinationen als Schlüsselfaktor für die Realisierung neuer touristischer Strukturen. In: Bieger, Th., Laesser, Ch. (Hrsg.): Neue Strukturen im Schweizer Tourismus - Der Weg der Schweiz. Zurich

Bieger, Th./ Müller H., et al. (1998): Neue Strukturen im Schweizer Tourismus - das Konzept. In: Bieger, Th., Laesser, Ch. (Hrsg.): Neue Strukturen im Schweizer Tourismus - Der Weg der Schweiz. Bern

Boehan, K., Mak, J.: Private versus public financing of state destination promotion. In: Journal of Tourism Research, fall/96.

Hammer, M./Champy J. (1993): Reengineering the corporation, New York

Heath, E., Wall, G. (1992): Marketig Tourism Destionations, New York

Inskeep, E.: Tourism Planning - An integrated and sustainable development approach, New York

Keller, P., Koch, K. (1995): Die Globalisierung des Tourismus, in: Die Volkswirtschaft 5/95, S. 16 - 22, Bern

De Keyser R. , Vanhove H.: Tourism quality plan: an effective tourism policy tool, in: The Tourist Review, 3/97.

Mühlenkamp, H. (1997): Notwendigkeit und Alternativen der öffentlichen Tourismusförderung, in: Tourismus Journal, 2/97, S. 239 -268.

Müller, H.R. (1996): Angebotsschwächen im Schweizer Tourismus, Bern

Olson, M. (1965): The logic of Collective Action, Cambridge, MA.

Poon, A. (1993): Tourism, technology and competitive strategies, Gildford

Thom, N. (1992): Organisationsentwicklung. In: Frese, E., (Hrsg.): Handwörterbuch der Organisation, 3. Aufl., Stuttgart Sp. 1477-1491.

Thom, N.(1997): Management des Wandels - Grundelemente für ein differenziertes und integriertes „Change Management“. In: Die Unternehmung, 3/97. 
Tschurtschenthaler, P. (1993): Umwelt und Tourismus, ein Allokations- und Distributionsproblem bei der Nutzung knapper Ressourcen, in: Langer, G., Weiermair, K., Tourismus und Landschaftsbild, Thaur/Wien/München, 1993.

Weiermair, K. (1996): Strukturwandel im alpinen Tourismus: Herausforderungen und Chancen, in: St. Galler Beiträge zum Tourismus und zur Verkehrswirtschaft, Reihe Tourismus, Band 30., Bern 